\title{
$\left[\begin{array}{ll}ノ & -\end{array}\right]$
}

\section{ポリ $\left[\boldsymbol{N}^{\delta}\right.$-(4-カルボキシベンジル)-L-オルニチン] 及びその保護誘導体の合成と構造}

\author{
早川忠男*1 - 井上 克彦*1 - 木村 忠司*1
}

（受付 1988 年 12 月 7 日・審査終了 1989 年 2 月 20 日）

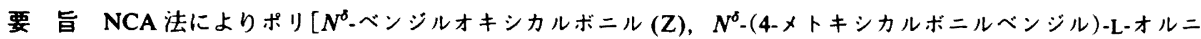
チン] (polymer 1) を合成した. polymer 1 をけん化によりポリ $\left[N^{\delta}-Z, N^{\delta}\right.$-(4-カルボキシベンジル)-L-オルニチン] (polymer 2) を，脱 Z 化によりポリ[ $N^{\delta}$-(4-メトキシカルボニルベンジル)-L-オルニチン] (polymer 3) とした.

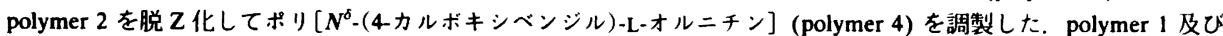
2 はへリックス促進溶媒中で $\alpha$-ヘリックス構造である. polymer 2, 3, 及び 4 の構造変化を水一アルコール混合溶媒 中で pH を変えながら検討した. polymer 2 は pH 7 12 の範囲で $\alpha$-ヘリックス構造である. polymer 3 は pH 6 以 下でランダムコイル構造であるが $\mathrm{pH} 7$ 以上では $\alpha$-ヘリックス構造になる. polymer 4 は pH 9 を境に同様な挙動を 示した.
\end{abstract}

1 緒言

著者らは先にポリ (L-リシン) やポリ（L-オルニチン） の側鎖了ミノ基にベンジル1), 2), メチルベンジル ${ }^{3)}$, 4-力 ルボキシベンジル4), 及び 3- または 4-ヒドロキシベンジ ル5)などのアルキル基や官能基を持つアルキル基を導入 した誘導体を合成し，側鎖基が主鎖構造に与える影響に ついて種々検討した。ポリ（L-リシン）側鎖アミノ基にべ ンジル, メチルベンジルが導入されたポリマーは水-1プロパノール $(1: 1, \mathrm{v} / \mathrm{v})$ 溶液中, 低 $\mathrm{pH}$ 側ではランダム コイル構造であるが $\mathrm{pH} 7$ 付近で $\alpha$-ヘリックス構造に転 移し，4-カルボキシベンジル基を導入したポリマーでは $\mathrm{pH} 10$ 付近，3-または4-ヒドロキシベンジル基を導入し たポリマーでは pH 7.7 付近で同様な挙動を示すことを 報告した。

今回は既報”之同様な方法によりポリ（しーオルニチン） 側銷アミノ基に4-カルボキシベンジル基を導入した両 性電解質のポリ $\left[N^{\delta}\right.$-(4-カルボキシベンジル)-L-オルニチ ン] 及びその宫能基を保護した 3 種のポリアミノ酸を合 成し，側鎖基が主鎖構造に及ぼす影響について赤外線吸 収 (IR) スペクトルや円偏光二色性 (CD) スペクトルな どの測定により検討したので報告する.

*1 信州大学織維学部高分子工業研究施設（ $\mathbf{W} 386$ 上田市常田 3-15-1)

\section{2 実 験}

\section{1 試料の合成}

2.1.1 $N^{a}$-Z-L-オルニチン Bezas ら ${ }^{6)}$ の $N^{a}$-Z-L-リシ ンの調製法と同様の方法により L-オルニチンとベンジル オキシカルボニルクロリドの反応により調製した。収㸉 $55.2 \%$. $\mathrm{mp} 183 \sim 184^{\circ} \mathrm{C} .[\alpha]_{\mathrm{D}}^{25}=-13.5^{\circ}(c, 1.0,1 \mathrm{~N} \mathrm{HCl})$. 分析 $\mathrm{C}_{13} \mathrm{H}_{18} \mathrm{~N}_{2} \mathrm{O}_{4}$ としての

計算値: C, $58.63 \% ; \mathrm{H}, 6.81 \% ; \mathrm{N}, 10.52 \%$.

分析值: C, $58.55 \% ; \mathrm{H}, 6.86 \% ; \mathrm{N}, 10.36 \%$.

2.1.2 $N^{a}-\mathrm{Z}, N^{\diamond}$-(4-メトキシカルボニルベンジル)-Lオルニチン $\quad N^{\alpha}$-Z-L-オルニチン $5.33 \mathrm{~g}$ と 4-メトキシカ ルボニルベンズアルデヒド $3.62 \mathrm{~g}$ をタノール $130 \mathrm{ml}$ とベンゼン $30 \mathrm{~m} /$ に溶かし，トリエチルアミン $2.8 \mathrm{ml}$ を 加え，既報4と同様の方法により調製した。収星 $5.5 \mathrm{~g}$ (66.3\%). $\mathrm{mp} 154 \sim 155^{\circ} \mathrm{C} . \quad[\alpha]_{\mathrm{D}}^{25}=8.7^{\circ}(c, 2.3,0.1 \mathrm{~N}$ $\mathrm{HCl}$ ). 分析 $\mathrm{C}_{22} \mathrm{H}_{26} \mathrm{~N}_{2} \mathrm{O}_{6}$ としての

計算值: C, 63.75\%; H, 6.32\%; N, 6.76\%.

分析值: C, 63.52\%; H, 6.32\%; N, 6.45\%.

2.1.3 $N^{a}, N^{0}-2 Z, N^{0}$-(4-メトキシカルボニルベンジ ル)・L-オルニチン・DCHA 䘏 2.1.2 で調製した $N^{a}-Z$, $N^{\delta}$-(4-メトキシカルボニルベンジル)-L-オルニチン 5.55 $\mathrm{g}$ と炭酸水素ナトリウム $1.13 \mathrm{~g}$ を水 $100 \mathrm{ml}$ とジオキサ ン $60 \mathrm{ml}$ の混合溶液に溶かし, ベンジルオキシカルボ二 ルクロリド $2.75 \mathrm{~g}$ と炭酸水素ナトリウム $1.36 \mathrm{~g}$ を扣え て既報出之同様に処理し、ジシクロへキシルアミン (DCHA) 塩として結晶化させた。結晶は酢酸エチルーへ キサンで再結晶した，収量 $7.95 \mathrm{~g}$ (81.4\%)， mp 124〜 
$126^{\circ} \mathrm{C} \cdot[\alpha]_{D}^{25}=7.79^{\circ}\left(c, 2.3\right.$, エタノール). 分析 $\mathrm{C}_{42} \mathrm{H}_{55} \mathrm{~N}_{3} \mathrm{O}_{8}$ としての

計算值：C, $69.11 \% ; \mathrm{H}, 7.60 \% ; \mathrm{N}, 5.76 \%$.

分析値：C, $69.24 \% ; \mathrm{H}, 7.52 \% ; \mathrm{N}, 5.72 \%$.

2.1.4 $N^{0}-\mathrm{Z}, N^{0}$-(4-メトキシカルボニルベンジル)-Lオルニチン・NCA 2.1.3で調製した DCHA 塩 $7.80 \mathrm{~g}$ を常法により DCHA を除去した $N^{a}, N^{\delta}$-2Z, $N^{\delta}$-(4-メト キシカルボニルベンジル)-L-オルニチンを既報4と同様 な万法により処理し, NCA の結晶を得た. 酢酸エチルー ヘキサンで再結晶した。収量 $3.80 \mathrm{~g}(80.7 \%)$. mp 120

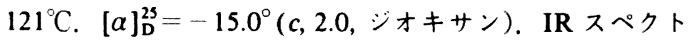
ルにより 1850 及び $1780 \mathrm{~cm}^{-1}$ に 5 員環無水物の吸収を 確認した。分析 $\mathrm{C}_{23} \mathrm{H}_{24} \mathrm{~N}_{2} \mathrm{O}_{7}$ としての

計算值: C, $62.72 \% ; \mathrm{H}, 5.49 \%$; N, 6.36\%.

分析值：C, $62.73 \% ; \mathrm{H}, 5.59 \% ; \mathrm{N}, 6.26 \%$.

2.1.5 ポリ $\left[N^{\delta}-\mathrm{Z}, N^{0}\right.$-(4-メトキシカルボニルヘンンシ ル)-L-オルニチン] (polymer 1) 2.1.4で調製した NCA $1.64 \mathrm{~g}$ をジオキサン $20 \mathrm{ml}$ に溶かし、トリエチルアミン を開始郕 $([M] /[1]=50)$ として加え, 室温で 1 週間重合 させた，高粘度のポリマー溶液をメタノール中に注入 し、析出するポリマーをろ別, 乾燥した。収量 $1.36 \mathrm{~g}$ (91.9\%). 分析 $\left(\mathrm{C}_{22} \mathrm{H}_{24} \mathrm{~N}_{2} \mathrm{O}_{5}\right)_{n}$ としての

計算值：C, $66.65 \% ; \mathrm{H}, 6.10 \% ; \mathrm{N}, 7.07 \%$.

分析値：C, $66.48 \% ; \mathrm{H}, 6.08 \% ; \mathrm{N}, 6.96 \%$.

polymer 1 のジメチルホルムアミド (DMF) 溶液の $25^{\circ} \mathrm{C}$ での極限粘度は $[\eta]_{\mathrm{DMF}}^{2 \mathrm{~S}}=0.47$ である. 分子量はポリ $\left(N^{\epsilon}\right.$ Z-L-リシン）の粘度式”に代入して算出すると約 100000 (重合度約 250) であった。

2.1.6 ポリ $\left[N^{0}-\mathrm{Z}, N^{0}\right.$-(4ーカルボキシベンジル)-L-オル

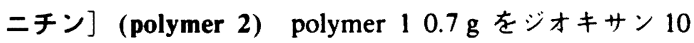
$\mathrm{m} l$ に溶かし、 $1 N \mathrm{NaOH} 3.6 \mathrm{~m} l$ とジオキサン $15 \mathrm{~m} l$ の混 合溶液を加え，既報出と同椂に処理してけん化した。収 量 $0.66 \mathrm{~g}(97.8 \%)$. 分析 $\left(\mathrm{C}_{21} \mathrm{H}_{22} \mathrm{~N}_{2} \mathrm{O}_{5}\right)_{n}$ としての

計算値: C, $65.96 \% ; \mathrm{H}, 5.80 \% ; \mathrm{N}, 7.33 \%$.

分析值：C, $65.58 \% ; \mathrm{H}, 5.79 \% ; \mathrm{N}, 7.25 \%$.

2.1.7 ポリ $\left[\boldsymbol{N}^{\text {- }}\right.$-(4メトキシカルボニルベンジル)-L-オ ルニチン・HBr] (polymer 3) polymer $10.40 \mathrm{~g}$ をジオ キサン $5 \mathrm{~m} l$ に溶かし， $25 \% \mathrm{HBr}$-水酢酸 $10 \mathrm{ml}$ を加え， 既報出と同様に調製した。収量 $0.28 \mathrm{~g}(80.0 \%)$ ，分析 $\left(\mathrm{C}_{14} \mathrm{H}_{19} \mathrm{~N}_{2} \mathrm{O}_{3} \mathrm{Br}\right)_{n}$ としての

計算値：C, $48.99 \% ; \mathrm{H}, 5.58 \% ; \mathrm{N}, 8.16 \%$.

分析值：C, $48.65 \% ; \mathrm{H}, 5.43 \% ; \mathrm{N}, 8.03 \%$.

2.1.8 ポリ $\left[N^{0}\right.$-(4-カルボキシベンジル)-L-オルニチ ン・HBr] (polymer 4) polymer $20.66 \mathrm{~g}$ をリフロロ 酢酸 $7 \mathrm{~m} /$ に溶かし， $25 \% \mathrm{HBr}$-水酷酸 $10 \mathrm{~m} /$ を加え，既 報4と同様に調製した，収量 $0.52 \mathrm{~g}(91.2 \%)$ ，分析 $\left(\mathrm{C}_{13} \mathrm{H}_{17} \mathrm{~N}_{2} \mathrm{O}_{3} \mathrm{Br}\right)_{n}$ としての

計算值：C, $47.43 \% ; \mathrm{H}, 5.20 \%$; N, $8.51 \%$.
分析値：C, $47.82 \% ; H, 5.10 \% ; \mathrm{N}, 8.30 \%$.

\section{2 測定方法}

粘度測定は polymer 1 をDMFに溶かし, Ubbelohde 型粘度計を用い, 温度 $25 \pm 0.05^{\circ} \mathrm{C}$ で固有粘度を測定し た. IR スペクトル（A-302 型，日本分光(株)製）は試料 を有機溶媒からキャストしたフィルムまたは KBr disk 法により測定した，CD スペクトルはCD-J40A（日本分 光(株)製）を用いて測定し，実験デー夕は平均残基棈鬥 率 degree $\mathrm{cm}^{2} / \mathrm{dmol}$ で表した。

\section{3 結果と考察}

\section{1 polymer 1 及び 2 の有機溶媒中における構造}

polymer 1 及び 2 はジオキサン, 2-クロロエタノール, テトラヒドロフラン, クロロホルムなどの有機溶媒に可 溶である。両ポリマーの上記の溶媒中における CD スペ クトルは先に報告したポリ $\left(N^{t}-Z \text {-L-リシン誘導(体) }\right)^{1)-S)}$ と 同様典型的な右まき $\alpha$-ヘリックス構造の挙動を示した. 両ポリマーともこれらの溶媒中における CD スペクト ルは 208 及び $222 \mathrm{~nm} に[\theta]_{208}=-24000 \sim-37000$, $[\theta]_{222}=-35000 \sim-38000$ の負の極值を示し, 両ポリ マーとも側鎖基の性質による大きな差はなかった，また ジオキサン溶液からキャストしたフィルムのIR スペク トルはいずれも $1650 \mathrm{~cm}^{-1}$ (アミドI) 及び $1545 \mathrm{~cm}^{-1}$ （アミドII）付近に吸収を示し，CD スペクトルの結果と 併せて考慮すると,これらのポリマーは $\alpha$-ヘリックス構 造をとっていると考えられる。

\section{2 polymer 2, 3, 及ひ 4 の水系溶媒中における構造}

polymer 2 は $\mathrm{pH} 8$ 以上の水溶液または水一メタノール $(1: 1, v / v)$, 水-2-クロロエタノール $(1: 1, v / v)$ などの混 合溶液では $\mathrm{pH} 7$ 以上で可溶である. polymer 2 を上記溶 媒系で $\mathrm{pH}$ を変化させながら $\mathrm{CD}$ スペクトルを測定し た. $\mathrm{pH} 7$ 付近から $\mathrm{pH} 12$ 付近の中〜塩基性 $\mathrm{pH}$ 領域では いずれも 208 及び $222 \mathrm{~nm} に[\theta]_{208}=-30000 \sim-34000$, $[\theta]_{222}=-31000 \sim-36000$ の極值をもつ $\alpha$-ヘリックス構 造特有の CD スペクトルを与える. 高 $\mathrm{pH}$ 側でわずかに $[\theta]$ 值は減少する傾向が見られたが大きな変化はなく， カルボキシラートは水に対する溶解度を增加させるが主 鎖の $\alpha$ ・ヘリックス構造には影響を与えないと考えられ る.

polymer 3 は水-2-クロロエタノール $(1: 1, \mathrm{v} / \mathrm{v})$ 混合溶 液中で、低 $\mathrm{pH}$ 側ではランタムコイル構造に特街的な $\mathrm{CD}$ スペクトルを与えるが, pH 7 付近より 208 及び 222 $\mathrm{nm}$ に負の極值が現れ, $\mathrm{pH}$ の增加に従って大きくなり $\mathrm{pH} 9$ で $[\theta]_{208}=-29000,[\theta]_{222}=-30000$ の極值をすつ $\alpha$-ヘリックス構造に転移する. $\mathrm{pH}$ 変化に基づく $[\theta]_{222}$ の値をプロットすると $\mathrm{pH} 7$ 付近より急激にランダムコ イル構造から $a$-ヘリックス構造に転移することが羿め られた。この現象は側鎖アミ/基の環境が同椂と考えら 


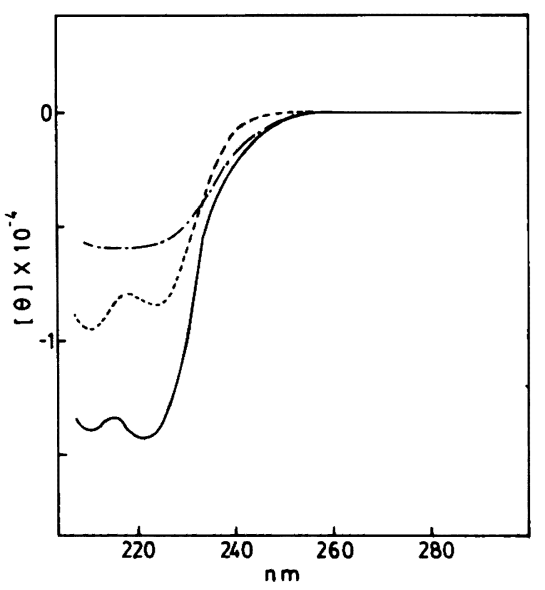

Fig. 1. CD spectra of polymer 4 as a function of $\mathrm{pH}$

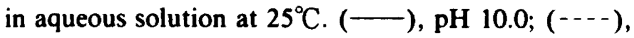
pH 10.3; (-•-•), pH 11.8 .

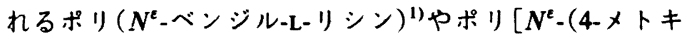
シカルボニルベンジル)-L-リシン］少の挙動に類似する.

側鎖の保護基をすべて除去した polymer 4 は pH 9.9 以 下では水に不溶であるが $\mathrm{pH} 10$ 以上では可溶となる.

Fig. 1 に polymer 4 の種々の $\mathrm{pH}$ 水溶液中の $\mathrm{CD}$ スペク トルを示した。 pH 10 で 208 及び $222 \mathrm{~nm}$ に $[\theta]_{208}=$ $-14000,[\theta]_{222}=-15000$ の極値をもつ部分的な $\alpha$-へ リックス構造であるが $\mathrm{pH}$ の增加に伴いこれらの極值は 减少し，ランタムコイル構造への移行が観察される。こ れは既報4)のポリ [ $N^{t}$-(4-カルボキシベンジル)-L-リシン] の場合と異なりポリ（し-オルニチン誘導体）ではメチレ ン基が 1 個少ないためカルボキシラート同士による反発 が主鎖構造に影響を与え， $a$-ヘリックス構造をとりにく くしていると考えられる.

低 $\mathrm{pH}$ 側の構造を調べるために水ートリフロロエ夕 ノール $(1: 1, v / v)$, 水-2-クロロエ夕ノール $(1: 1, v / v)$, 及び水-1-プロパノール $(1: 1, v / v)$ 混合溶液中で CD ス ペクトルの測定を行い, Fig. 2 に pH 変化に伴う $[\theta]_{222}$ の値のプロットを示した. pH 3.5〜8 の間は等電点によ る沈殿を生じポリマーが析出するので測定できなかっ た. pH 3.5 以下の低 pH 側ではこれらの溶媒中でほぼラ ンダムコイル構造と考えられ，pH 9 以上になると 222 $\mathrm{nm}$ の極值が増加し， $\alpha$-ヘリックス構造に転移するもの と考えられる. いずれの溶媒でも転移中点は $\mathrm{pH} 8.3 \sim$ 9.3 である. polymer 4 の pH 変化に伴う上記の構造変化

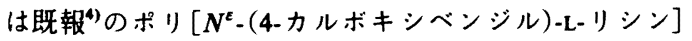
の挙動とほぼ同様であるが, 両者のへリックス構造で存 在する $\mathrm{pH}$ 領域での $[\theta]_{222}$ の值はポリ（L-リシン誘導体） $\left([\theta]_{222}=33000\right)$ の方が大きく, ポリ $(\mathrm{L}-$ オルニチン誘導 体) $\left([\theta]_{222}=24000\right)$ では小さく現れるのでへリック構造

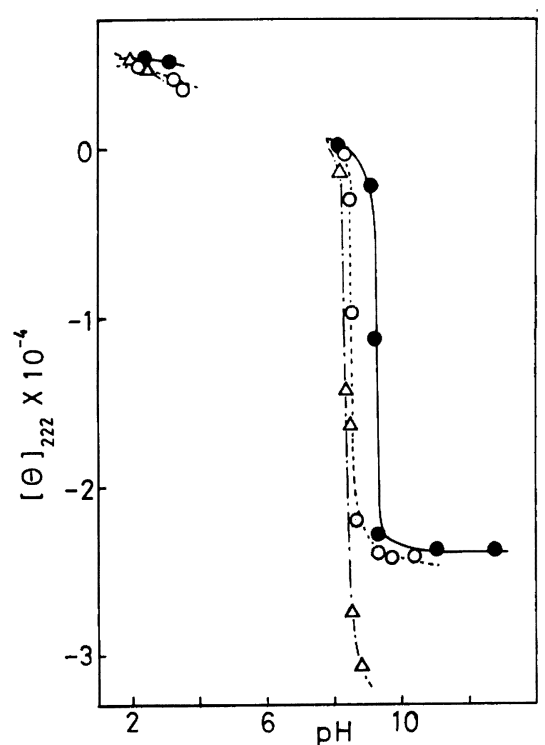

Fig. 2. Plots of ellipticities at $222 \mathrm{~nm}$ of polymer 4 as a function of $\mathrm{pH}$ in a water-alcohol $(1: 1, \mathrm{v} / \mathrm{v})$ mixture at $25^{\circ} \mathrm{C} .(\triangle)$, water-trifluoroethanol; $(O)$, water-2-chloroethanol; ( $\odot)$, water-1-propanol.

の安定性に差があると考えられる.

\section{4 結 論}

NCA 法により polymer 1 を合成し, polymer 1 の保護 基を一部または全部除去して polymer 2 , polymer 3 , 及び polymer 4 を調製した. polymer 1 及び 2 はジオキサン, テトラヒドロフラン，2-クロロエタノール中で $\alpha$-ヘリッ クス構造である. polymer 3 は水-2-クロロエタノール混 合溶液中で低 $\mathrm{pH}$ 側ではランダムコイル構造であるが pH 7 付近より $\alpha$-ヘリックス構造に転移する. polymer 2 のように $\delta$ 位アミノ基が保護されているとカルボキシ ル基が存在していても水ーアルコール系混合溶液中全 $\mathrm{pH}$ 領域で $\alpha$-ヘリックス構造である。この現象はカルボ キシラートは溶解性を増加させるが主鎖構造にはほとん ど影響を与えないものと考えられる。保護基をすべて除 去した polymer 4 の測定した水ーアルコール系溶液やの $\mathrm{pH}$ 変化に伴う構造変化は既報4)のポリ $\left[N^{e}-(4\right.$ - カルボキ シベンジル)-L-リシン] とほぼ同様の挙動を示した。 pH 3.5 以下及び双性イオン構造となりポリマーが析出する pH 3.5 8 の領域では側鎖アミノ基は解離状態であり, 主鎖はランダムコイル構造として存在し, pH 9 付近に なるとアミノ基は非解離状態となって $\alpha$-ヘリックス構 造に転移するものと考えられる。

\section{文献}

1) H. Yamamoto and T. Hayakawa, Biopolymers, 11, 1259 
(1972).

2) H. Yamamoto, T. Hayakawa, and J. T. Yang, Biopolymers, 13, 1117 (1974)

3) 早川忠男, 近藤慶之, 山田具由, 中川晴葴, 日本化学会誌, 1346 (1974).

4) 早川忠男、井上克彦、木村忠司，高分子論文集，44, 711
(1987).

5) 早川忠男, 井上克彦, 国枝誠, 山䗁浩一, 高分子論文集, 45, 641 (1988).

6) B. Bezas and L. Zervas, J. Am. Chem. Soc., 83, 719 (1961).

7) M. Matsuoka, T. Norisuye, A. Teramoto, and H. Fujita, Biopolymers, 12, 1515 (1973).

\section{[Notes]}

Synthesis and Conformation of Poly[ $N^{\circ}$-(4-carboxybenzyl)-L-ornithine] and Its Protected Derivatives

Tadao HAYAKaWA*1, Katsuhiko INOUYE*1, and Tadashi KIMURA*1

${ }^{* 1}$ Institute of High Polymer Research, Faculty of Textile Science and Technology, Shinshu University

(3-15-1, Tokida, Ueda, 386 Japan)

Poly [ $N^{\delta}$-benzyloxycarbonyl, $N^{\delta}$-(4-methoxycarbonylbenzyl)-L-ornithine] (polymer 1) was prepared by the $N$ carboxyanhydride method. The fully protected polymer was converted into poly[ $N^{\delta}$-benzyloxycarbonyl, $N^{\delta}$-(4carboxybenzyl)-L-ornithine] (polymer 2), poly [ $N^{\delta}$-(4-methoxycarbonylbenzyl)-L-ornithine] (polymer 3 ) and poly [ $N^{\delta}$ (4-carboxybenzyl)-L-ornithine] (polymer 4) through saponification and debenzyloxycarbonylation. The results of the CD measurements of polymers 1 and 2 suggested that these polymers had an $\alpha$-helical conformation in helix-promoting solvents. Conformational changes of polymes 2,3 , and 4 were studied as a function of $\mathrm{pH}$ in a water and alcohol (1: $1, \mathrm{v} / \mathrm{v}$ ) mixture. Polymer 2 existed in a helical conformation in a pH range 7-12. Below $\mathrm{pH} 6$, polymer 3 existed in a random coil structure, but, when $\mathrm{pH}$ was increased to more than 7, the spectra gradually changed into those of $\alpha$-helix structure. Polymer 4 exhibited similar behavior at $\mathrm{pH} 9$.

KEY WORDS Synthesis / Conformation / Poly [ $\boldsymbol{N}^{\delta}$-(4-carboxybenzyl)-L-ornithine] / Circular Dichroism /

Coil to Helix Transition /

(Received December 7, 1988: Accepted February 20, 1989)

[Kobunshi Ronbunshu, 46(6), 381-384 (1989)] 